\title{
A Critical Access on Improving Productivity and Livelihood of Handloom Weavers
}

\author{
G.Ramakrishnan, B.Poongodi, C.Velmurugan, G.Mohamed Zakriya
}

\begin{abstract}
Weight of traditional jacquard machine is reduced by modifying its components dimension and size. Pneumatic and electric lifting mechanism adopted on jacquard machine handloom and its productivity was studied and compared with traditional jacquard machine. Its productivity and earnings are discussed in this paper to enhance the livelihood of handloom weavers.
\end{abstract}

Keywords - Handlooms, Jacquard, Productivity, Earnings. Lifting mechanism

\section{INTRODUCTION}

Handloom is a cause of livelihood for the millions of Indians directly or indirectly and meets the clothing requirements of the masses related to glorious tradition of socio-economic fabric of society [1-4]. But the handloom weavers are no longer continuing with handloom and they were shifted to other jobs. Thus, technological change (power-loom), low wages and rising price of yarn (raw material) have adversely affected the handloom sector as well as handloom weavers [5]. A novel pattern of production at moderate cost, good sales design and modernization of handloom can be solved the crisis situation of the handloom weavers. [6]

At present, due to socio - economic condition and industry high employment potential causes existing of weavers from handloom in India is quiet common [1].This situation create demand on handloom market segment and necessitates productivity of handloom by small group of weavers. The handloom weavers get low wages for their low productivity [5]. A handloom weaver gets usually rupees 500 to rupees 800 for weaving a cotton sari which took 4 to 5 days. The wage ranges and time to complete a single sari depend on designs and complexity of a sari. The manufacturing wages rate of Banaras sari is high comparatively than other saris. If a weaver weaves a Banaras sari, he/she gets rupees 2000 to rupees 3000 and time given for making the sari is 15 to 20 days [5].

In this research work, at solving the challenges faced by hand loom weavers particularly the use of heavy weight jacquards attached to the hand loom. The force required to be put on the pedal by the weaver's leg to lift the jacquard hooks. Hence the pains remain high while weaving a sari. The operation of weaving a sari of length 6.2 meters and

\footnotetext{
Revised Manuscript Received on August 14, 2019.

Dr.G.Ramakrishnan, Deaptment of Fashion Technology Kumaraguru college of Technology Coimbatore, T.N. India (ramakrishnan.g.ft@kct.ac.in)

Dr.B.Poongodi, Bussiness School, Kumaraguru college of Technology Coimbatore, T.N. India

Dr.C.Velmurugan, Deaptment of Mechanical Engineering Kumaraguru college of Technology Coimbatore, T.N. India

Dr.G.Mohamed Zakriya Deaptment of Fashion Technology Kumaraguru college of Technology Coimbatore, T.N. India
}

weight of approximately 600 grams takes nearly $15-18$ man hours. This makes the weavers to experience a lot of leg pain/knee pain and finally fatigue makes the weaver to discontinue the operation and take rest. By this the productivity is decreased which has a negative impact on the family income.

\section{EXPERIMENTAL}

\section{A. Materials and Methods}

\section{TABLE I. WEAVING PARTICULARS}

\begin{tabular}{|l|l|l|}
\hline S.No & Particulars & specification \\
\hline 1 & Yarn & Soft Silk \\
\hline 2 & $\begin{array}{l}\text { Count } \\
\text { (Warp and Weft) }\end{array}$ & 36 Denier \\
\hline 3 & Denting & 4 ends / dent \\
\hline 4 & Reed count & 40 s \\
\hline 5 & Loom width & 49 inches \\
\hline
\end{tabular}

The weight reduction for lifting bars, linking rods, sliding cylinder rod were made and the diameter of jacquard hook is also reduced in modified jacquard machine. The pedaling force was completely eliminated by incorporating pneumatic lifting system and electric lifting instead of manual pedaling. Through this method the leg /knee pain and fatigue of weavers were completely eliminated. Using Likert scale analysis, physical tolerance of handloom weaver was studied on fabrication of fabric using above said weaving particulars as shown in Table.I on all kind of handloom machines. The study revealed as observed that the weavers were completely free of any physical fatigue when using pneumatic and electric lifting system and significant reduction in the physical fatigue while using modified jacquard. Besides improving the quality and productivity, spending for medical treatments related fatigue of weaving process is considerably reduced. 


\section{RESULTS}

A. Physical strains of handloom weavers

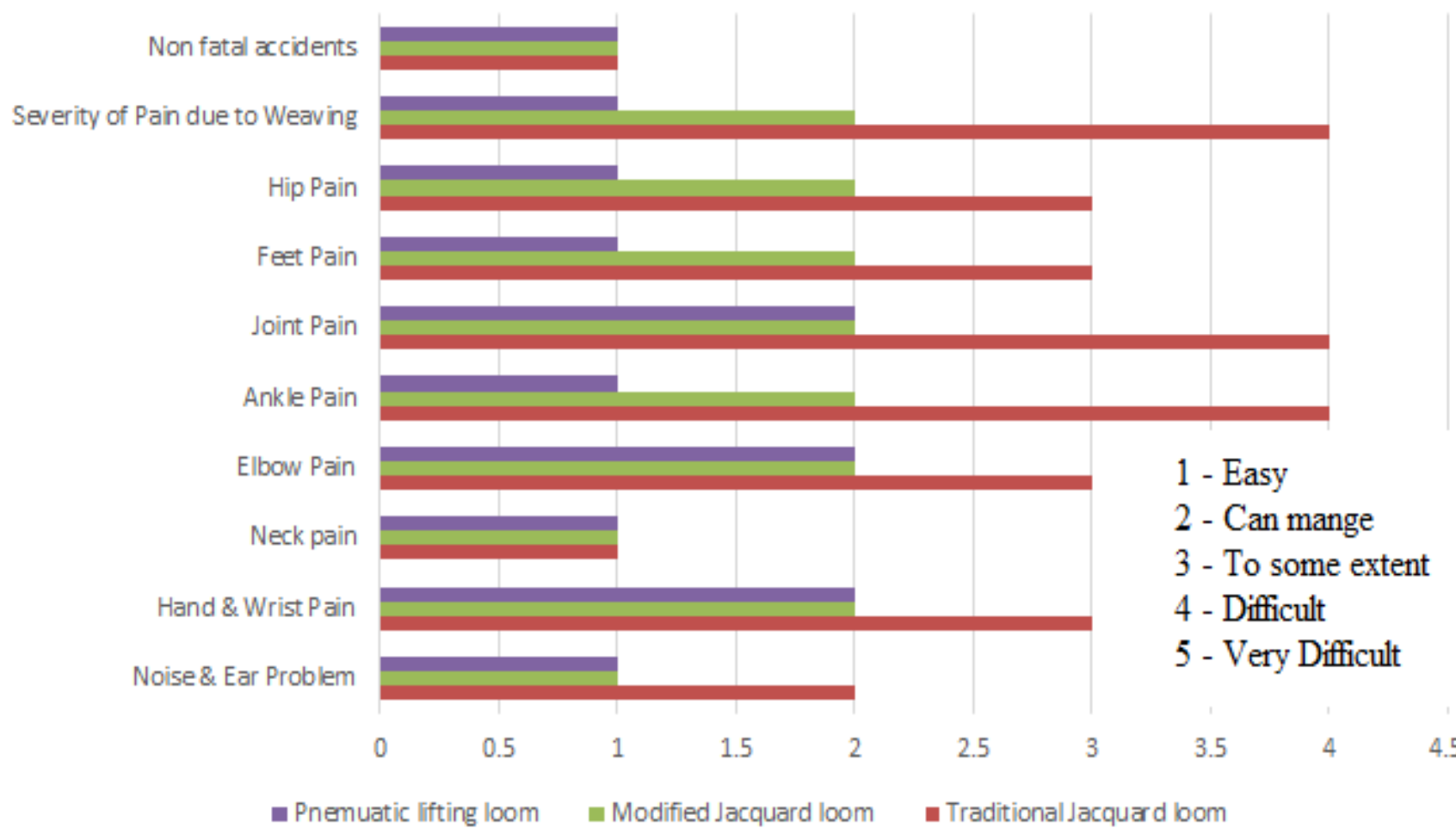

Fig. 1. Assessment of physical strains on jacquard handlooms

From the Figure 1. It is clearly depicted that pneumatic and electric jacquard hand loom process shows less fatigue compare to all other handloom weaving. Compared to traditional jacquard loom modified jacquard loom were shows less fatigue of weavers. Compare to traditional jacquard hand loom, the modified jacquard loom weight is reduced up to $10 \mathrm{~kg}$. Ankle pain and feet pain were reduced while using pneumatic and electric lifting hand

looms. Hand, wrist, Joint pain and Elbow pain were remaining same as in modified jacquard loom. Based on the weaving design factors, the scale level may be varied. This study on physical strain assessment of handloom weaver was done at Handloom field study centre at Chinna Aranmani, Samathur, Pollachi.

\section{B. Assessment Of Productivity}

TABLE II. ASSESSMENT OF PRODUCTIVITY THROUGH FIELD TRIAL

\begin{tabular}{|c|c|c|c|c|c|c|c|}
\hline $\begin{array}{l}\text { Type of jacquard } \\
\text { operation }\end{array}$ & EPI & PPI & $\begin{array}{l}\text { Time in hrs } \\
\text { per metre of } \\
\text { fabric }\end{array}$ & $\begin{array}{l}\text { Time in hrs to } \\
\text { complete one } \\
\text { sari }\end{array}$ & $\begin{array}{l}\text { Width of } \\
\text { fabric in } \\
\text { inches }\end{array}$ & $\begin{array}{l}\text { Force required to } \\
\text { lift the jacquard } \\
\text { hooks in kgf }\end{array}$ \\
\hline Traditional Jacquard loom & 192 & 72 & 6 & 37 & 47 & 65 & 5.5 \\
\hline $\begin{array}{c}\text { Modified Jacquard loom } \\
\text { Pneumatic \& Electric } \\
\text { lifting hand loom }\end{array}$ & 192 & 72 & 4 & 25 & 47 & 65 & 4.0 \\
\hline
\end{tabular}

While calculating productivity, the same constructional parameters were considered. As discussed in physical strain of the jacquard hand loom weavers, the associated tiredness factors varied based on the jacquard machine selection. Due to that, productivity is varied. Pneumatic and electric lifting handloom gives good productivity. When it is taken in the consideration of additional cost investment or electricity supply aspects modified jacquard yield good result. Manual pedaling force required to lift the jacquard machine is drastically low in modified jacquard hand loom compared to traditional jacquard machine.

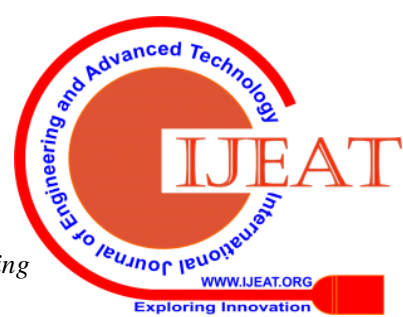




\section{Earnings on Handlooms}

TABLE III. HAND LOOM PRODUCTIVITY VS EARNING WAGES (APPROXIMATE CALCULATION)

\begin{tabular}{|c|c|c|c|}
\hline Factors & Traditional jacquard & Modified jacquard & $\begin{array}{l}\text { Pneumatic and Electric } \\
\text { lifting hand loom }\end{array}$ \\
\hline Working hours per day & $9 \mathrm{hrs}$ & $12 \mathrm{hrs}$ & $12 \mathrm{hrs}$ \\
\hline Therefore, for month & $270 \mathrm{hrs} / \mathrm{month}$ & $360 \mathrm{hrs} / \mathrm{month}$ & $360 \mathrm{hrs} / \mathrm{month}$ \\
\hline $\begin{array}{l}\text { Time taken to complete one silk } \\
\text { saree }\end{array}$ & $\begin{array}{l}37 \mathrm{hrs} \\
\text { (from our field study) }\end{array}$ & $\begin{array}{l}25 \mathrm{hrs} \\
\text { (from our field study) }\end{array}$ & $\begin{array}{l}19 \mathrm{hrs} \\
\text { (from our field study) }\end{array}$ \\
\hline Wages for completing one silk saree & Rs.800 (Basic design) & Rs.800 (Basic design) & Rs.800 (Basic design) \\
\hline Therefore, Saree produced/ month & $\begin{array}{l}270 / 37 \\
\text { sarees/month }\end{array}$ & $360 / 25=14.4$ sarees/month & $360 / 19=18.94$ sarees/month \\
\hline Earning wages / month & $\begin{array}{l}7.29 \times 800 \\
\text { Rs.5,838/month }\end{array}$ & $\begin{array}{l}14.4 \times 800 \\
\text { Rs. } 11,520 / \text { month }\end{array}$ & $\begin{array}{l}18.94 \times 800 \\
\text { Rs. } 15,158 / \text { month }\end{array}$ \\
\hline
\end{tabular}

Tiredness variation differed in types of jacquard machine, in pneumatic and electric lifting jacquard machine; a person can work up to $12 \mathrm{hrs}$ and complete a sari approximately at $19 \mathrm{hrs}$. Average income for the person is Rs.15, 158/- per month. Without any additional investment on modified jacquard machine it comes around Rs.11, 520/- per month. Compared to traditional jacquard machine the income is 2 to 3 times higher in modified jacquard and auto lifting handlooms.

\section{CONCLUSION}

From the above study and research work, the DST SEED project team suggested to use modified jacquard box mechanism to survive in handloom industry without any additional cost setup. Rather than, pneumatic and electric lifting mechanism of jacquard handloom, modified jacquard machine is economical and profitable. Immediate care and attention on handloom weaver's fatigues reduction, allocation of right time funds for the upliftment of handloom family is essential to meet the demands of national and international market.

\section{ACKNOWLEDGMENT}

Authors of this paper thanks the Department of Science and Technology - Science for Equity Empowerment \& Development (DST-SEED) wing, for this sanctioned Project No.SSP/TIASN/NF/002/2014 (C \& G). Sincerely extend the heartfelt thanks to our management of Kumaraguru College of Technology for providing space and essential facilities to establish the Handloom Field study centre at Chinna Aranmani, Samathur, Pollachi to conduct these studies. Further we extend our thanks to Technology Information Forecasting Assessment Council - Centre of Relevance Excellence (TIFAC CORE - KCT) for its technical supports. We also thank KCT-TIFAC CORE for their technical support.

\section{REFERENCE}

1. Srinivasa Rao, D., Dr. N.Sreedhar, (2017). Problems of Handloom Weavers in Andhra Pradesh: A Study of Krishna District, International Journal of Humanities and Social Science Invention, Vol.6, Volume 6 Issue 11,November. 2017, PP.01-08 ISSN (Online): 2319 7722, ISSN (Print): $2319-7714)$

2. Gurumoorthy.T.R, \& Rengachary.R.T. (2002). Problems of Handloom Sector. In Soundarapandian.M (Ed.), Small Scale Industries: Problems (Vol. 1, pp. 168-178). New Delhi: Concept Publishing House.

3. Mathiraj.S.P, \& RajKumar.P. (2008, March). Analytical study on Handloom products-production and marketing. Tamilnadu Journal of Cooperation , pp. 69-73

4. Narasaiah, L., \& Krishna, T. (1999). "Crisis of Handloom Industry". New Delhi: Discovery Publishing House.

5. Shaw Tanusree (2015). A Study of the Present Situation of the Traditional Handloom Weavers of Varanasi, Uttar Pradesh, India, A Study of the Present Situation of the Traditional Handloom Weavers of Varanasi, Uttar Pradesh, International Research Journal of Social Sciences, Vol. 4(3), 48-53, March.

6. Mathiraj S.P. and Raj Kumar P. (2008), Analytical study on Handloom products production and marketing, Tamilnadu Journal of Cooperation, 69-73. 